$\xi=$

\title{
Isolation and screening of kojic acid producing isolate of Aspergillus oryzae potentially applicable for production from sugarcane molasses
}

\author{
Abdel-Hamied M. Rasmey *, Aya H. Basha \\ Department of Botany and Microbiology, Faculty of Science, Suez University, Suez, Egypt \\ *Corresponding author E-mail:am_rasmey@yahoo.com
}

\begin{abstract}
Kojic acid is an organic acid produced as secondary metabolite by different fungi specially Aspergillus species. Isolation of a novel fungal strain potential for kojic acid production from agro-industrial wastes was the main purpose of the present study. Kojic acid was estimated in the current investigation colorimetric by 2,6-dichlorophenolindophenol (DCIP). A total of 43 fungal isolates belonging to seven species of Aspergillus recovered from stored wheat grains and dust air were screened for their ability to produce kojic acid. Ten isolates of them belonging to A. oryzae and A. flavus var. columnaris produced high concentrations $(16.818 \pm 0.006-43.917 \pm 0.389 \mathrm{~g} / \mathrm{l}) \mathrm{of}$ kojic acid from glucose. The secondary screening of these ten isolates for kojic acid production from glucose, sucrose, starch, maltose and cellulose as different carbon sources resulted that $A$. oryzae $124 \mathrm{~A}$ was the highly producer on glucose and sucrose recording $44.189 \pm$ 0.079 and $32.135 \pm 0.298 \mathrm{~g} / \mathrm{l}$, respectively. A. oryzae $124 \mathrm{~A}$ produced $15.022 \pm 0.017 \mathrm{~g} / \mathrm{l}$ of kojic acid from the pretreated semisynthetic sugarcane molasses. The maximum concentration $(29.431 \pm 0.001 \mathrm{~g} / \mathrm{l})$ of kojic acid production by A. oryzae 124A from sugarcane molasses was obtained when the fungus grown on $5 \%$ sugarcane molasses adjusted at $\mathrm{pH} 3.5$ and incubated at $28^{\circ} \mathrm{C}$ for 19 days. The recorded results suggested that $A$. oryzae $124 \mathrm{~A}$ could be used as a promising candidate for utilization in kojic acid fermentation from sugarcane molasses on industrial scale.
\end{abstract}

Keywords: Fermentation; Kojic Acid; Molasses; Optimization; Pretreatment.

\section{Introduction}

Aspergillus flavus are an important group of species in food mycology, medical mycology and biotechnology. Most species cause food spoilage, but on the other hand are also used in the fermentation industry to produce hydrolytic enzymes and organic acids. Non-aflatoxigenic species such as $A$. oryzae have been widely used in industry for food fermentation or enzymes production (Geiser et al. 1998). Different organic acids produced by Aspergillus oryzae such as citric, gluconic, itaconic and kojic acid. Kojic acid known as 5-hydroxy-2-hydroxymethyl- $\gamma$-pyrone is a weak organic acid produced as a major secondary metabolite by Aspergillus oryzae from carbohydrates in aerobic fermentation process (Rosfarizan et al. 2010, Hazzaa et al. 2013). This organic acid was originally isolated in Japan by Saito in 1907 from mycelia of Aspergillus oryzae grown on steamed rice (El-Aasar 2006).

Kojic acid has several economic uses in various fields. In food industries, Kojic acid is distributed naturally in traditional Japanese food such as miso, soy sauce and sake, thus, endowing these various food types with special tastes, colours and flavours (Wood 1998). kojic acid is now used as an additive to prevent browning of food materials, and as an antioxidant (Bentley 2006, Nohynek et al. 2004, Rosfarizan et al. 2010, Yasunobu et al. 2010) due to its inhibitory effect on polyphenol oxidase in different foods (Saruno et al. 1978, Chen et al. 1991). The inhibitory effect of kojic acid on polyphenol oxidase is associated to the inhibition of melanosis by interfering the uptake of oxygen required for enzymatic browning, and reduction of o-quinones to diphenols to prevent the formation of the final pigment (melanin) or the combination of the above actions (Rosfarizan et al. 2010).

Kojic acid and its derivatives possess antibacterial properties against gram-negative as well as gram-positive bacteria and antifungal agent (Kotani et al. 1976, Hassan et al. 2014). Besides its antibiotic functions, kojic acid also shows a certain insecticidal activity against Heliothis zea and Spodoptera frugiperda insects and it has been employed as a chelating agent for the production of insecticides (Buchta 1982, Dowd 1988). Also, kojic acid continues to attract attention because of its economic potential in medical field as an anti-inflammatory drug (Jignesh et al. 2014).

The most striking benefit of kojic acid is found in cosmetic and health care industries due to its ability to act as the ultra violet protector, whereby, it suppresses hyperpigmentation in human skins by restraining the formation of melanin through the inhibition of tyrosinase formation, the enzyme that is responsible for skin pigmentation (Noh et al. 2009). At present, kojic acid is primarily used as the basic ingredient for excellent skin lightener in cosmetic creams, where it is used to block the formation of pigment by the deep cells on the skins (Masse et al. 2001). In addition, kojic acid and its manganese and zinc complexes can potentially be used as radio protective agents, particularly against $\gamma$-ray (Emami et al. 2007). Recently, methods for the synthesis of various kojic acid derivatives, such as kojic acid ester, kojic acid laureate and kojic acid dipalmitate have been reported in many studies (Brtko et al. 2004, Lee et al. 2006, Khamaruddin et al. 2008, Ashari et al. 2009). Also, it has been reported that kojic acid can be easily conjugated with chitosan to produce kojic acid-chitosan conjugates, suggesting that kojic acid has a potential use in chemi-

Copyright @ (2016Abdel-Hamied M. Rasmey, Aya H. Basha. This is an open access article distributed under the Creative Commons Attribution License, which permits unrestricted use, distribution, and reproduction in any medium, provided the original work is properly cited. 
cal industry (Guibal 2004, Synytsya et al. 2008). Moreover, in chemical industries it has been successfully used to make azo-dyes and biodegradable compounds (Hassan et al. 2014).

Among the used substrates for kojic acid production is the sugarcane molasses as by-product of sugar industries in Egypt. Molasses are cheap raw materials, readily available, and ready for conversion with limited pretreatments as compared with starchy or cellulosic materials. Sugarcane molasses is a dark viscous fluid and rich in sugar and some nutrients required by most microorganisms. Therefore, the current study was conducted to screen for the kojic acid producing ability among different Aspergillus species isolated from starchy grains and air and also to optimize kojic acid production by the selected highly producer isolate from sugarcane molasses.

\section{Materials and methods}

\subsection{Samples collection and Fungi isolation}

The investigated fungi in the present work were isolated from two habitats as following:

\subsubsection{Dust air samples}

Twenty dust air sampling from the outdoor of different sectors at Sues University was performed during the evening in winter season using the settle plate method according to Hoekstra et al (2004). The plates were exposed for 15 minutes in each exposure, sealed and transferred immediately to the laboratory for incubation.

\subsubsection{Wheat grain samples}

Twenty samples of stored wheat grains were collected randomly from the markets at Suez, Egypt for isolation of associated mycoflora. The isolation was performed by dilution plate method according to Christensen (1963).

The collected fungi were isolated on Sabouraud dextrose agar (SDA) medium contained $\left(\mathrm{g} / \mathrm{l}\right.$ dist. $\left.\mathrm{H}_{2} \mathrm{O}\right)$ : dextrose, 40.0; peptone, 10.0 and agar, 18.0 supplemented with chloroamphenicol (50 $\mu \mathrm{g} / \mathrm{ml}$ ) and rose bengal $(10 \mu \mathrm{g} / \mathrm{ml}$ ) (in order to minimize the appearance of bacteria). The culture medium was adjusted to $\mathrm{pH} 6.5$ using $\mathrm{HCl} 0.1 \mathrm{~N}$ and $\mathrm{NaOH} 0.1 \mathrm{~N}$ and autoclaved at $121^{\circ} \mathrm{C}$ for 15 minutes. The plates were incubated at $28^{\circ} \mathrm{C}$ for 10 days. The growing fungal colonies were picked up, sub-cultured on fresh SDA plates, transferred to fresh agar slants and stored at $4^{\circ} \mathrm{C}$. The results were expressed as colony forming units (CFU).

\subsection{Fungi Identification}

The isolated fungi were identified at the genus and species level according to the detailed study of all the microscopic morphological characters and the macroscopic features of their colonies according to Moubasher (1993).

\subsection{Fermentation medium for kojic acid production}

The fermentation medium for kojic acid production consists $(\mathrm{g} / \mathrm{L})$ : Glucose, 60; yeast extract 5; $\mathrm{KH}_{2} \mathrm{PO}_{4}, 1.5$ and $\mathrm{MgSO}_{4}, 0.5$ adjusted at $\mathrm{pH} 3.5$ was used in screening experiments. The experimental cultures were grown in $250 \mathrm{~mL}$ Erlenmeyer flasks, each containing $50 \mathrm{~mL}$ of the synthetic medium. The flasks were sterilized at $121^{\circ} \mathrm{C}$ for $15 \mathrm{~min}$ and inoculated after cooling with one $\mathrm{mL}$ of inoculum spores suspensions $\left(5 \times 10^{6}\right.$ spores per $\left.\mathrm{mL}\right)$. The cultures were incubated at $28 \pm 2^{\circ} \mathrm{C}$ as static cultivation for 8 days.

\subsection{Detection of kojic acid production}

Kojic acid concentration was estimated quantitatively in culture filtrates by a colorimetric method based on the reaction between kojic acid and 2,6-dichlorophenolindophenol (DCIP) according to Tanigaki et al. (1980).

\subsection{Kojic acid fermentation from different carbon} sources

Different carbon sources (glucose, sucrose, starch, maltose and cellulose) were individually added to the basal fermentation medium in such amount equivalent to $60 \mathrm{~g} / \mathrm{l}$ of carbon. The cultures were incubated at $28 \pm 2^{\circ} \mathrm{C}$ as static cultivation for 12 days.

\subsection{Sugarcane molasses pretreatment}

Sugarcane molasses was purchased from Sugars and Integrated Industries Egyptian Distillation Plants in Hawamdeia City, Giza, Egypt and stored at $4{ }^{\circ} \mathrm{C}$. The clarification of molasses was conducted according to Shashank (1994). The molasses were diluted using distilled water to prepare molasses with $6 \%$ sugar concentration and the $\mathrm{pH}$ of the diluted molasses was adjusted to 3.5 using concentrated sulfuric acid. The molasses is heated to about $95^{\circ} \mathrm{C}$ in water bath for 15 minutes and the heated diluted molasses was left to settle for at least 2 hours to precipitate the sludge. The treated molasses was filtered and the cleared supernatant was transferred to the fermentation flasks.

\subsection{Optimized conditions for kojic acid production from sugarcane molasses by $A$. oryzae 124A}

The effects of different initial $\mathrm{pH}$ values $(3.0,3.5,4.0,4.5,5.0$, 5.5, 6.0 and 6.5), different molasses sugar concentrations (3-10\%) with $1 \%$ interval, different incubation temperatures $\left(5-45^{\circ} \mathrm{C}\right)$ and different fermentation periods $(7-21$ days) on kojic acid production by the selected isolate were estimated.

\subsection{Statistical analysis}

Analysis of variance (ANOVA) was performed using CoStat V. 6.311 (CoHort software, Berkeley, CA94701). Kojic acid production mean values were compared at $5 \%$ significance level using Tukey's test.

\section{Results and discussion}

\subsection{Isolation of fungi from dust air and wheat grains}

The total count of fungi isolated from the air of Suez University area was $204 \mathrm{CFU} / 5 \mathrm{~h}$. A total of 20 fungal species plus to two species varieties belonging to 12 genera were isolated and identified. Aspergillus was the most dominant genus emerged in 18 out of 20 tested exposures and recorded $35.78 \%$ of total fungal count. Aspergillus was represented by A. carbonarius, A. flavus var. flavus, A. flavus var. columnarius, A. oryzae, A. sulphureus and A. niger. The most common species of Aspergillus was A. flavus and recorded with moderate occurrence while the other isolated species were recorded as low or rare occurrence. Many researchers in different studies on isolation of airborne fungi reported that the most prevalent fungi were belonged to genus Aspergillus (Durugbo et al. 2013, Menezes 2004, Chakrabarti et al. 2012, Kalyoncu 2012, Sen and Asan 2009, Horner et al. 2004). Alternaria comes behind Aspergillus in the occurrence where isolated from 10 out of the 20 tested exposures representing $14.22 \%$ of isolated total fungal count. It was represented by the two species A. alternata and $A$. phragmospora in low frequencies. Cladosporium and Cochliobolus ranked the third genera with regard to the number of cases of isolation. Both of the two genera were recorded with low occurrence. These results are in agreement with ShamsGhahfarokhi et al. (2014). The predominance of Aspergillus, Alternaria, Cladosporium and Cochliobolus may be due to the ability of these genera produce numerous small and light spores that generally remain in the air for a long period of time, whereas other 
fungal genera produce fewer, larger and heavier spores which tend to have faster settling (Vonberg \& Gastmeier 2006). The other isolated genera were recorded with low frequencies and listed in table (1) and figure (1)

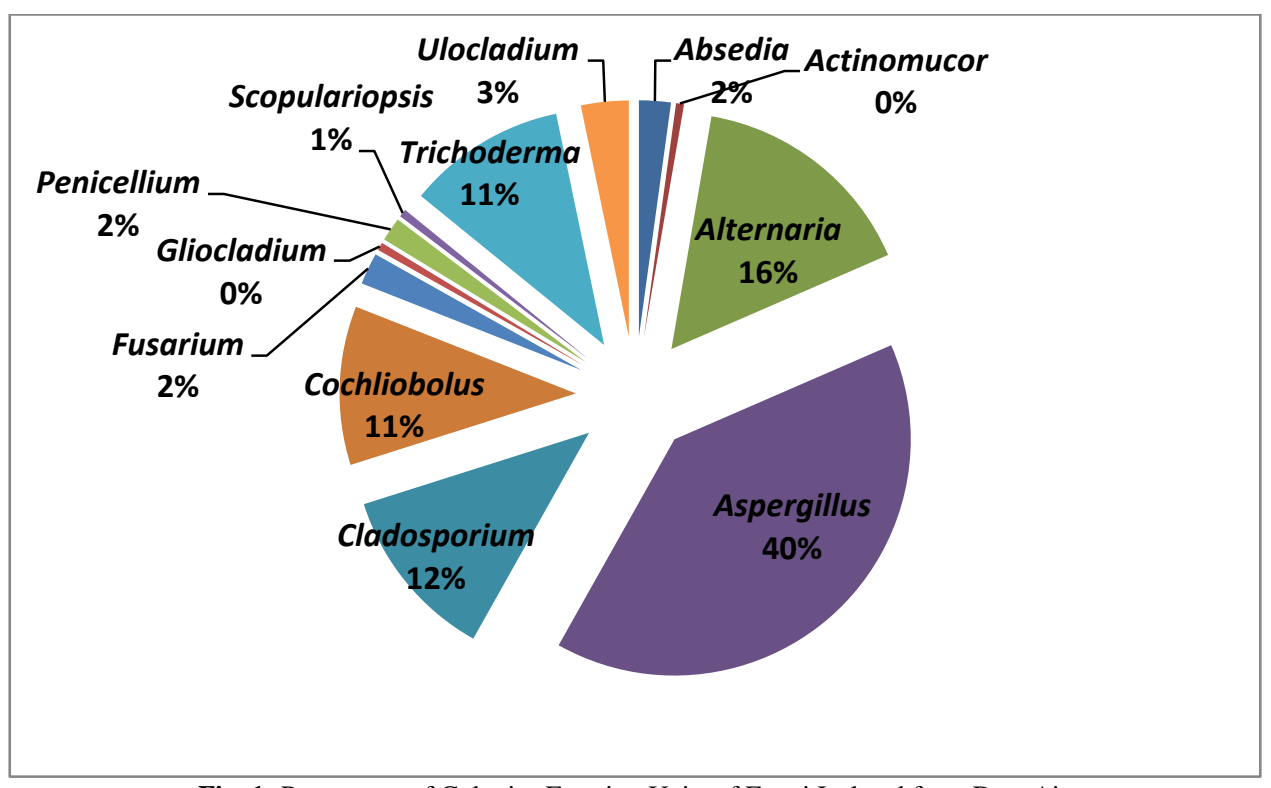

Fig. 1: Percentage of Colonies Forming Units of Fungi Isolated from Dust Air.

Table 1:Fungal Genera and Species Isolated from 20 Outdoor Air Samples Collected from Suez University

\begin{tabular}{|c|c|c|c|c|}
\hline Genera \& Species & Total CFU/5h & $\% \mathrm{CFU}$ & $\mathrm{NCI}$ & OR \\
\hline Absidia corymbifora & 4 & 1.96 & 1 & $\mathrm{R}$ \\
\hline Actinomисоr elegans & 1 & 0.49 & 1 & $\mathrm{R}$ \\
\hline Alternaria & 29 & 14.22 & 10 & M \\
\hline A. alternata & 18 & 8.82 & 6 & $\mathrm{~L}$ \\
\hline A. phragmospora & 11 & 5.39 & 5 & $\mathrm{~L}$ \\
\hline Aspergillus & 73 & 35.78 & 18 & $\mathrm{H}$ \\
\hline A. carbonarius & 11 & 5.39 & 8 & $\mathrm{~L}$ \\
\hline A. flavus var. flavus & 37 & 18.14 & 13 & M \\
\hline A. flavus var. columnaris & 2 & 0.98 & 1 & $\mathrm{R}$ \\
\hline A. oryzae & 7 & 3.43 & 5 & $\mathrm{~L}$ \\
\hline A. sulphureus & 1 & 0.49 & 1 & $\mathrm{R}$ \\
\hline A. niger & 15 & 7.35 & 6 & $\mathrm{~L}$ \\
\hline Cladosporium & 22 & 10.78 & 8 & $\mathrm{~L}$ \\
\hline C. cladosporiodies & 2 & 0.98 & 1 & $\mathrm{R}$ \\
\hline C. herbarium & 20 & 9.80 & 7 & $\mathrm{~L}$ \\
\hline Cochliobolus & 20 & 9.80 & 8 & $\mathrm{~L}$ \\
\hline C. australiensis & 1 & 0.49 & 1 & $\mathrm{R}$ \\
\hline C. luntus & 1 & 0.49 & 1 & $\mathrm{R}$ \\
\hline C. spicifer & 18 & 8.82 & 7 & $\mathrm{~L}$ \\
\hline Fusarium lateritium & 4 & 1.96 & 2 & $\mathrm{R}$ \\
\hline Gliocladium catenulatum & 1 & 0.49 & 1 & $\mathrm{R}$ \\
\hline Penicellium oxalicum & 3 & 1.47 & 2 & $\mathrm{R}$ \\
\hline Scopulariopsis brevicaulis & 1 & 0.49 & 1 & $\mathrm{R}$ \\
\hline Trichoderma harzianum & 20 & 9.80 & 1 & $\mathrm{R}$ \\
\hline Ulocladium atrum & 6 & 2.94 & 3 & $\mathrm{R}$ \\
\hline Total & 204 & 100.00 & & \\
\hline
\end{tabular}

CFU: Colony forming units, NCI: Number of cases of isolation, OR: Occurrence remark

In a survey for isolation of fungi from stored wheat grains during this study, a total of 12 species plus two species varieties belonging to five genera were isolated and identified. The isolated genera were Absidia (one species), Aspergillus (six species), Candida sp., Cladosporium (one species) and Penicillium (three species). Recent reports have been also made on the occurrence of fungi in stored seeds (Rasmey 2009, El-Shanshoury et al. 2014, Reddy et al. 2009, Rustemeyer et al. 2010, Soliman 2003). Aspergillus was the most common genus and recorded with high occurrence from 16 out of the 20 tested samples with $69.31 \%$ of total fungal count The most frequent species of Aspergillus were A. niger and A. sulphureus emerged in 11 and 10 samples out of 20 tested samples, respectively. The obtained results are consistent with Soliman (2003) who reported that Aspergilllus was the predominant and most frequent fungus in the collected wheat grains in his study. Penicillium was the second common genus where occurred in 10 out of the 20 tested samples and recorded $27.88 \%$ of total fungal count. It was represented by the three species $P$. brevicompactum, $P$. chrysogenum and $P$. duclauxii. $P$. duclauxii was appeared with low frequency while the other two species were recorded as rare occurrence among the other isolated fungi. These obtained results are in agreement with that of Kacaniova \& Tancinova (2001) who found that out of 24 genera isolated from feeding wheat, Aspergillus and Penicillium were the most frequently isolated. Also in a similar study, Al-Kahtani (2014) reported that the most common genera were Alternaria (isolated from $68.96 \%$ of the tested samples), Aspergillus (24.14\%) and in a lesser extent Fusarium (6.9\%). The remaining isolated genera from the tested wheat grain samples were recorded with rare occurrence and listed in table (2)and figure (2). Microorganism propagules get on grain in different ways, most often with dust from soil, from 
the surface of plant remnants during harvesting, transportation, storage and processing (Klich 2002).

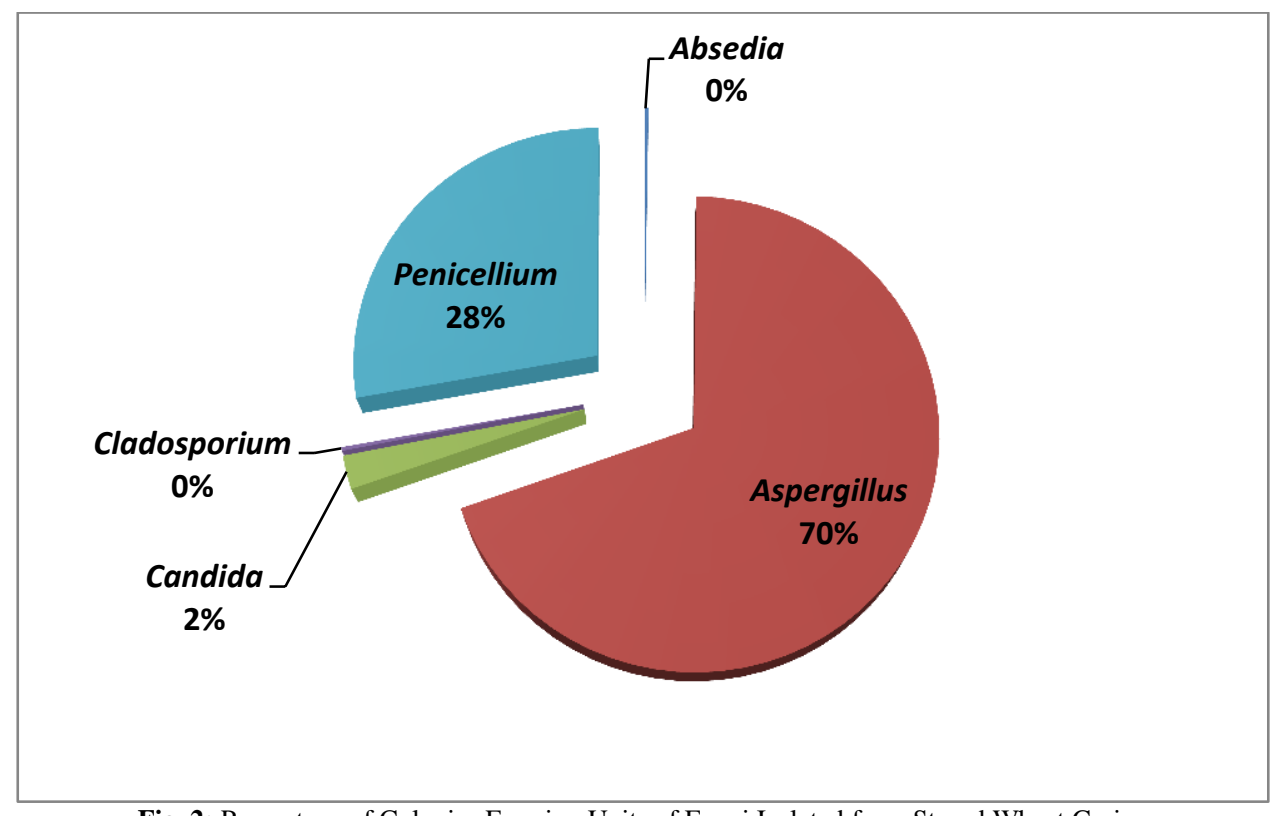

Fig. 2: Percentage of Colonies Forming Units of Fungi Isolated from Stored Wheat Grains.

Table 2: Fungal Genera and Species Isolated from 20 Wheat Grain Samples Collected from Suez University

\begin{tabular}{|c|c|c|c|c|}
\hline Genera \& Species & Total CFU/20 g & $\% \mathrm{CFU}$ & $\mathrm{NCI}$ & OR \\
\hline Absidia corymbifera & 100 & 0.26 & 1 & $\mathrm{R}$ \\
\hline Aspergillus & 27100 & 69.31 & 16 & $\mathrm{H}$ \\
\hline A. cervinus & 100 & 0.26 & 1 & $\mathrm{R}$ \\
\hline A. flavus var. flavus & 900 & 2.30 & 4 & $\mathrm{R}$ \\
\hline A. flavus var. Columnaris & 800 & 2.05 & 1 & $\mathrm{R}$ \\
\hline A Oryzae & 600 & 1.53 & 3 & $\mathrm{R}$ \\
\hline A. niger & 8000 & 20.46 & 11 & M \\
\hline A. sulphureus & 16600 & 42.46 & 10 & M \\
\hline A. terreus & 100 & 0.26 & 1 & $\mathrm{R}$ \\
\hline Candida sp. & 900 & 2.30 & 2 & $\mathrm{R}$ \\
\hline Cladosporium herbarium & 100 & 0.26 & 1 & $\mathrm{R}$ \\
\hline Penicellium & 10900 & 27.88 & 10 & M \\
\hline P. brevicompactum & 300 & 0.77 & 1 & $\mathrm{R}$ \\
\hline P. chrysogenum & 900 & 2.30 & 4 & $\mathrm{R}$ \\
\hline P. duclauxii & 9700 & 24.81 & 5 & $\mathrm{~L}$ \\
\hline Total & 39100 & 100.00 & & \\
\hline
\end{tabular}

\subsection{Screening of kojic acid production by the isolated Aspergillus species}

A total of forty three isolates of the recovered fungi representing eight species with two species varieties belonging to Aspergillus were screened for their potentiality to produce kojic acid from glucose as the sole carbon source in liquid synthetic medium under aerobic condition. Glucose was used in screening of kojic acid producing Aspergillus species since it is the simplest sugar (ElKady et al. 2014). The tested Aspergillus species were A. flavus var. flavus (six isolates), A. flavus var. columnaris (ten isolates), A. parasiticus (one isolate), A. oryzae (ten isolates), A. niger (ten isolates), A. cervinus (one isolate), A. sulphureus (one isolate), A. carbonarius (one isolate) and $A$. terreus (three isolates). All the tested isolates of each of $A$. parasiticus, A. niger, A. cervinus, $A$ sulphureus, $A$. carbonarius and $A$. terreus were negative for kojic acid production. Also, two isolates of each of A. flavus var. flavus and $A$. oryzae in addition to four isolates of A. flavus var. columnaris were unable to produce kojic acid. High concentrations (> $15 \mathrm{~g} / \mathrm{l}$ ) of kojic acid were produced by only two isolates of $A$. flavus var. columnaris (codes 120 and 218) and eight isolates of $A$. oryzae (codes 142, 152, 144, 124A, 120A, 231, 226 and 201). Moderate concentrations $(5-15 \mathrm{~g} / \mathrm{l})$ of kojic acid were detected by only two isolates of A. flavus var. flavus (codes 146 and 110 ) while low concentrations $(<5 \mathrm{~g} / \mathrm{l})$ of kojic acid were obtained by two isolates of A. flavus var. flavus and four isolates of A. flavus var. columnaris. It is worth mentioning that the most highly producer isolates for kojic acid were belonging to A. oryzae (table 3). The above mentioned Aspergillus species were also recorded in different studies as kojic acid producers (Ogawa et al. 1995, Ariff et al. 1997, Burdock et al. 2001, Futamura et al. 2001, Sahasrabudhe and Sankpal 2001, Gad 2003, El-Aasar 2006, El-Kady et al. 2014). Among the kojic acid producing Aspergillus species, A. flavus (Bajpai 1982, Ariff et al. 1996) and A. oryzae (Kitada et al. 1967, Kwak \& Rhee 1992, El-Aasar 2006) were reported to produce high concentrations of kojic acid. Kojic acid may be produced by different fungi especially Aspergillus species, but the commercial production is performed by A. oryzae and A. flavus using glucose as carbon substrate.

\subsection{Kojic acid production from different carbon sources by the highly producer isolates}

The influence of various carbon sources such as glucose, sucrose, starch, maltose and cellulose on kojic acid production by the selected highly producer isolates of Aspergillus was studied. The results in table (4) revealed that glucose was the most suitable carbon source for kojic acid production by the all ten tested isolates of Aspergillus followed by sucrose and starch. A. oryzae 142 was able to produce high concentration of kojic acid from starch as sole carbon source and recorded $31.576 \pm 0.404 \mathrm{~g} / \mathrm{l}$. kojic acid 
was not detected when the tested isolates grown on maltose or cellulose as sole carbon source in the fermentation medium. Carbon source plays the most important role in kojic acid production since it supplies the energy for the cell, substrate for kojic acid production and functions as biosynthesis of cellular constituents like carbohydrates proteins, lipids, nucleic acids and many more. Utilization of different carbon sources such as glucose, starch, sucrose, maltose and cellulose by different Aspergillus species for kojic acid production were studied by different authors (Kitada et al. 1967, Rosfarizan \& Ariff 2000). Sahasrabudhe \& Sankpal (2001) reported that Kojic acid producing do not require specific carbon sources since all of the cultures are able to utilize various carbon sources like glucose, fructose, sucrose, maltose, and mixture of glucose and sucrose. It is well known that glucose is the best carbon source for kojic acid production due to the similarity of its structure to that of kojic acid (Kitada et al. 1967, Basappa et al.1970). Kitada et al. (1967) and Megalla et al. (1986) suggested that, during the fermentation, kojic acid is formed directly from glucose without any cleavage of the carbon chain into smaller fragments. Kitada et al. (1967) reported that the highest yield of kojic acid produced by $A$. oryzae was obtained in the fermentation using glucose as carbon source, followed by sucrose. In a similar study, El-Aasar (2006) reported that glucose also have yield highest kojic acid production by $A$. parasiticus and followed by sucrose and beet molasses. A. oryzae 124A was the most highly producer isolate in the current investigation for kojic acid production from glucose and sucrose, so it was selected for production of kojic acid from sugarcane molasses in the further experiments.

Table 3: Screening of Kojic Acid Production by Some Aspergillus Isolates Recovered From Wheat Grains and Dust Air

\begin{tabular}{|c|c|c|c|c|}
\hline Fungal species & Isolation source & Isolate code & Kojic acid $(\mathrm{g} / \mathrm{L}) \pm \mathrm{SE}$ & Remark \\
\hline \multirow{6}{*}{ A. flavus var. flavus } & \multirow{3}{*}{ Air } & 146 & $13.693 \pm 0.065$ & M \\
\hline & & 157 & 0.000 & $\mathrm{~N}$ \\
\hline & & 110 & $12.399 \pm 0.130$ & M \\
\hline & \multirow{3}{*}{ Wheat grains } & 233 & 0.000 & $\mathrm{~N}$ \\
\hline & & 242 & $3.519 \pm 0.013$ & $\mathrm{~L}$ \\
\hline & & 133 & 0.000 & $\mathrm{~N}$ \\
\hline \multirow{9}{*}{ A. flavus var. columnaris } & \multirow{7}{*}{ Air } & 149 & $1.937 \pm 0.013$ & $\mathrm{~L}$ \\
\hline & & 136 & 0.000 & $\mathrm{~N}$ \\
\hline & & 102 & 0.000 & $\mathrm{~N}$ \\
\hline & & 108 & 0.000 & $\mathrm{~N}$ \\
\hline & & 147 & $0.674 \pm 0.006$ & $\mathrm{~L}$ \\
\hline & & 120 & $32.437 \pm 0.006$ & $\mathrm{H}$ \\
\hline & & 239 & $0.958 \pm 0.194$ & $\mathrm{~L}$ \\
\hline & \multirow[t]{2}{*}{ Wheat grains } & 230 & $1.150 \pm 0.039$ & $\mathrm{~L}$ \\
\hline & & 218 & $32.673 \pm 0.019$ & $\mathrm{H}$ \\
\hline \multirow[t]{3}{*}{ A. parasiticus } & \multirow[t]{3}{*}{ Air } & 129 & 0.000 & $\mathrm{~N}$ \\
\hline & & 124 & 0.000 & $\mathrm{~N}$ \\
\hline & & 103 & 0.000 & $\mathrm{~N}$ \\
\hline \multirow{7}{*}{ A. oryzae } & \multirow[t]{5}{*}{ Air } & 152 & $43.917 \pm 0.389$ & $\mathrm{H}$ \\
\hline & & 144 & $39.678 \pm 0.324$ & $\mathrm{H}$ \\
\hline & & $124 \mathrm{~A}$ & $43.904 \pm 0.045$ & $\mathrm{H}$ \\
\hline & & $120 \mathrm{~A}$ & $30.518 \pm 0.001$ & $\mathrm{H}$ \\
\hline & & 231 & $38.918 \pm 0.026$ & $\mathrm{H}$ \\
\hline & \multirow[t]{2}{*}{ Wheat grains } & 226 & $35.964 \pm 0.130$ & $\mathrm{H}$ \\
\hline & & 201 & $17.906 \pm 0.065$ & $\mathrm{H}$ \\
\hline A. niger & Air & $104,112,126,101,134,121,148,151,130 \& 176$ & 0.000 & $\mathrm{~N}$ \\
\hline A. cervinus & Wheat grains & 212 & 0.000 & $\mathrm{~N}$ \\
\hline A. sulphureus & Wheat grains & 204 & 0.000 & $\mathrm{~N}$ \\
\hline A. carbonarius & Wheat grains & 205 & 0.000 & $\mathrm{~N}$ \\
\hline A. terreus & Wheat grains & $208,203 \& 211$ & 0.000 & $\mathrm{~N}$ \\
\hline \multicolumn{5}{|c|}{ H: High kojic acid production $(>15 \mathrm{~g} / \mathrm{l})$} \\
\hline \multicolumn{5}{|c|}{ M: Moderate kojic acid production $(5-15 \mathrm{~g} / \mathrm{L})$} \\
\hline \multicolumn{5}{|c|}{ L: Low kojic acid production $(<5 \mathrm{~g} / \mathrm{l})$} \\
\hline \multicolumn{5}{|c|}{$\mathrm{N}$ : negative } \\
\hline
\end{tabular}

Table 5: Kojic Acid (G/L) Production from Different Carbon Sources by the Selected Highly Producer Ten Aspergillus Isolates

\begin{tabular}{|c|c|c|c|c|c|}
\hline Isolates Code & $\begin{array}{l}\text { Kojic acid (g/l) } \\
\text { Glucose }\end{array}$ & Sucrose & Starch & Lactose & Cellulose \\
\hline A. oryzae 152 & $40.736 \pm 0.023$ & $19.925 \pm 0.447$ & $12.522 \pm 0.365$ & - ve & - ve \\
\hline A. oryzae 144 & $42.222 \pm 0.127$ & $25.527 \pm 0.251$ & $7.058 \pm 0.675$ & - ve & - ve \\
\hline A. oryzae 231 & $25.719 \pm 1.273$ & $9.716 \pm 0.229$ & $0.169 \pm 0.029$ & - ve & - ve \\
\hline A. oryzae 226 & $26.567 \pm 0.623$ & $8.754 \pm 0.927$ & $0.0591 \pm 0.000$ & - ve & - ve \\
\hline A. oryzae $124 \mathrm{~A}$ & $44.189 \pm 0.079$ & $32.135 \pm 0.298$ & $11.735 \pm 0.070$ & - ve & - ve \\
\hline A. oryzae $120 \mathrm{~A}$ & $43.3581 \pm 0.005$ & $29.688 \pm 0.093$ & $6.491 \pm 0.721$ & - ve & - ve \\
\hline A. oryzae 201 & $43.393 \pm 0.150$ & $14.724 \pm 0.332$ & $0.126 \pm 0.038$ & - ve & - ve \\
\hline A. oryzae 142 & $39.958 \pm 0.175$ & $21.787 \pm 0.277$ & $31.576 \pm 0.404$ & - ve & - ve \\
\hline A. flavus var. columnaris 218 & $34.504 \pm 0.294$ & $10.398 \pm 0.753$ & $8.256 \pm 0.490$ & - ve & - ve \\
\hline A. flavus var. columnaris 120 & $38.245 \pm 0.649$ & $25.344 \pm 0.846$ & $12.915 \pm 0.0491$ & - ve & - ve \\
\hline
\end{tabular}

\subsection{Kojic acid production from sugarcane molasses by Aspergillus oryzae 124A}

An attempt to use sugarcane molasses as natural medium for kojic acid production by $A$. oryzae $124 \mathrm{~A}$ was investigated in the current study. The possibility of using waste carbon sources as suitable substrates for kojic acid production using Aspergillus species was studied by El-Kady et al. (2014). Egyptian sugarcane molasses contain about $52 \%$ as total sugar (glucose, sucrose, and fructose), $0.46 \%$ as total nitrogen in addition to detectable amounts of some vitamins such as riboflavin and thiamin (Khalifa 2003). Presence of these compounds in each of molasses and may favor kojic acid production (El-Kady et al. 2014). Three different molasses media 
for kojic acid production by the selected isolate A. oryzae 124A were tested. The three media were; M1 (untreated $6 \%$ molasses sugar without any nutrients supplementation); M2 (pretreated $6 \%$ molasses sugar without any nutrients supplementation) and M3 (pretreated $6 \%$ molasses sugar supplemented with $5.0 \mathrm{~g} \mathrm{~L}^{-1}$ yeast extract, $1.0 \mathrm{~g} \mathrm{~L}^{-1} \mathrm{KH}_{2} \mathrm{PO}_{4}$ and $0.5 \mathrm{~g} \mathrm{~L}^{-1} \mathrm{MgSO}_{4} \cdot 7 \mathrm{H}_{2} \mathrm{O}$ ). The results in figure (3) revealed that the pretreated sugarcane molasses supplemented with yeast extract as nitrogen source in addition to salts was suitable than the untreated molasses for kojic acid production by $A$. oryzae 124A. Generally, kojic acid production levels by the tested fungal isolate grown on sugarcane molasses under investigation was relatively low comparing to those levels produced by the same fungal isolate on synthetic medium of glucose or sucrose.

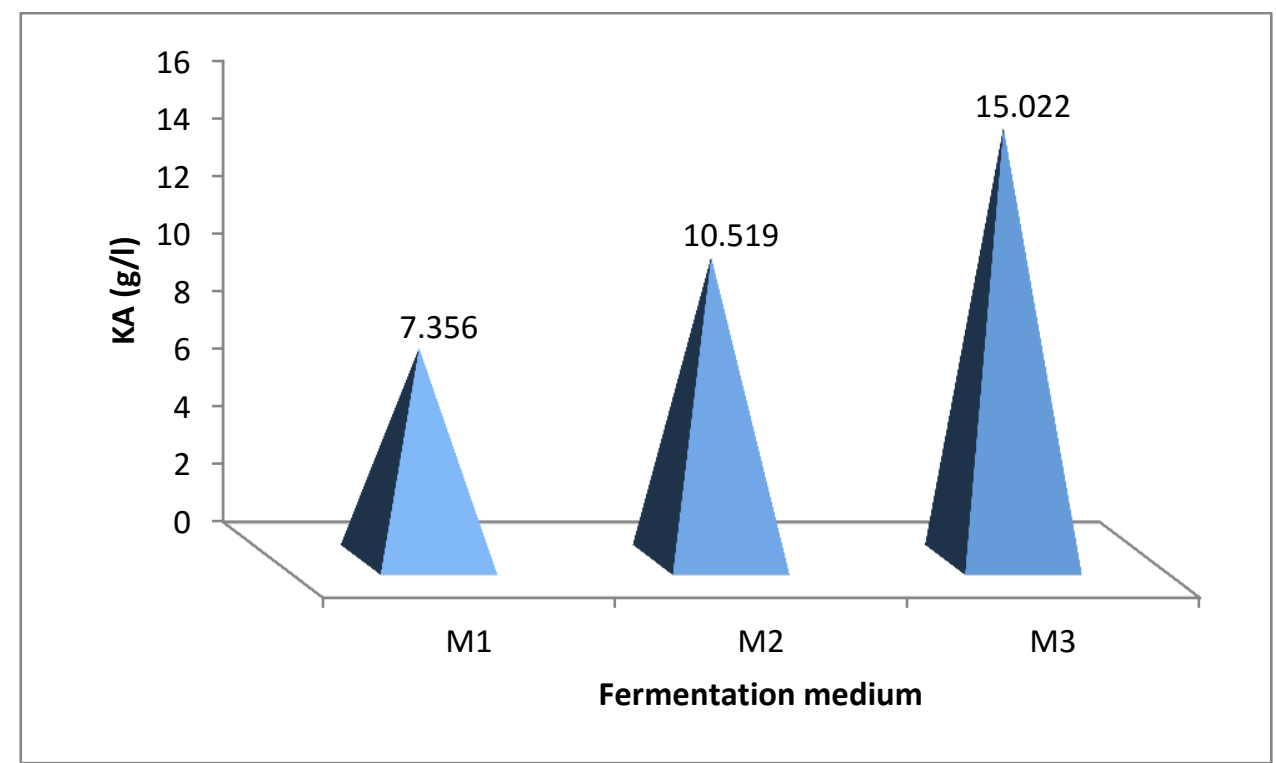

Fig. 3: Effect of Different Sugarcane Molasses Media on Kojic Acid Production by A. Oryzae 124A.

Sugarcane molasses as byproduct was relatively suitable substrate for kojic acid production by A. oryzae 124A. Therefore, the pretreated semisynthetic medium (M3) of sugarcane molasses was selected to determine the effect of cultural conditions on the efficiency of kojic acid production by A. oryzae 124A in order to maximize the produced amount of kojic acid by the tested isolate.

\subsection{Optimization of kojic acid production from sugar- cane molasses by $A$. oryzae $124 \mathrm{~A}$}

\subsubsection{Effect of pH on kojic acid production}

The effect of initial $\mathrm{pH}$ value in molasses fermentation medium on the production of kojic acid from sugarcane molasses by A. oryzae 124A was studied and the obtained results were presented in figure (4). The optimum $\mathrm{pH}$ for kojic acid production by the tested isolate was 3.5. The production of kojic acid began to decrease above $\mathrm{pH}$ 3.5. Most studies conducted on the effects of culture $\mathrm{pH}$ towards the growth and production of kojic acid was based on the initial culture $\mathrm{pH}$ (Lin et al. 1976, Clevstrom \& Ljunggren 1985). Several fungi like A. oryzae and A. flavus have the ability to produce kojic acid at $\mathrm{pH}$ range of 3 to 7 (Rosfarizan et al. 2000). Lin (2001) reported that $\mathrm{pH}$ optima for kojic acid production were 4.5and 6.5 for A. flavus and A. oryzae respectively. Lekha \& Lomane (1997) reported that enzymes, being proteins, contain ionizable groups; consequently, the $\mathrm{pH}$ of the culture medium effects their structure and function. The optimal $\mathrm{pH}$ is very important to be determined since it can greatly affected the optimum production of enzymes required for kojic acid production. Filamentous fungi, generally, are characteristically tolerant to acidic $\mathrm{pH}$ and most of them have an optimum $\mathrm{pH}$ between 5 and 6 for cellular growth and several metabolic activities (Rosfarizan et al. 2000). High $\mathrm{pH}$ may lead to the growth of microorganism or inhibition of enzymes activities responsible for the biosynthesis of kojic acid.

\subsubsection{Effect of incubation temperature on kojic acid produc- tion}

Kojic acid production from sugarcane molasses by the selected isolate was effected by the incubation temperature and it was noticed from the data that $A$. oryzae $124 \mathrm{~A}$ was able to grow considerable well and produce kojic acid within a temperature range from $20^{\circ} \mathrm{C}$ to $35^{\circ} \mathrm{C}$ (figure 5). The optimum incubation temperature for kojic acid production was recorded at $28^{\circ} \mathrm{C}$. The optimum temperature for kojic acid production by fungi indifferent studies was found to be $25-30^{\circ} \mathrm{C}$ (Futamura et al. 2001, Lin 2001, Gad 2003, El-Kady et al. 2014).

\subsubsection{Effect of sugar concentration on kojic acid production}

Data presented in figure (6) showed that the concentration of kojic acid increased along with the increase in molasses sugar concentration and reached the maximum kojic acid (19.930 g/l) at $5 \%$ sugar. Further increasing in sugar molasses concentration resulted in decreasing the produced kojic acid concentration. Gad (2003) studied the effect of beet molasses concentration on kojic acid production by A. parasiticus. Some molasses sucrose during sugar processing is hydrolyzed into reducing sugar glucose and fructose in sugarcane molasses which converted to kojic acid. Above a critical substrate concentration, a decreased water activity and onset of plasmolysis combine to cause a decrease in the rates of fermentation (Roukas 1993). Increasing initial sugar concentration resulted in a significant increase in residual sugar, which may be due to inability of the microorganisms to metabolize high levels of sugar. The osmotic pressure apparently had an unfavorable effect since the production of the acid dropped off sharply. These results agreed exactly with the early results found by May et al. (1931). Kojic acid synthesis only started after growth reached stationary phase and stopped when glucose in the medium was depleted (Kitada et al. 1967, Megalla et al.1985, Rosfarizan et al. 1998, Futamura et al. 2001). Rosfarizan\& Ariff (2000) and El-Aasar (2006) reported that the excess concentration of carbon source affects the production of kojic acid and resulted in significant 
increase in residual sugar due to the inability of fungi to metabolize high levels of sugar.

\subsubsection{Effect of incubation time on kojic acid production}

Influence of incubation time on kojic acid formation from sugarcane molasses by $A$. oryzae $124 \mathrm{~A}$ was studied and the recorded results in figure (7). Data showed that the formation of kojic acid gradually increased by increasing the incubation time of the cul- ture until reached the maximum value $(29.431 \mathrm{~g} / \mathrm{l})$ at 19 days then decreased. These results are in harmony with that previously obtained by Ariff et al. (1997), El-Kady et al. (2014) and El-Assar (2006). The reduction of kojic acid with extension of incubation time may be attributed to degradation of kojic acid to oxalic and acetic acid by the mycelium under glucose depleted conditions (Bajpai 1982, Mohamed \& Ariff 2007).

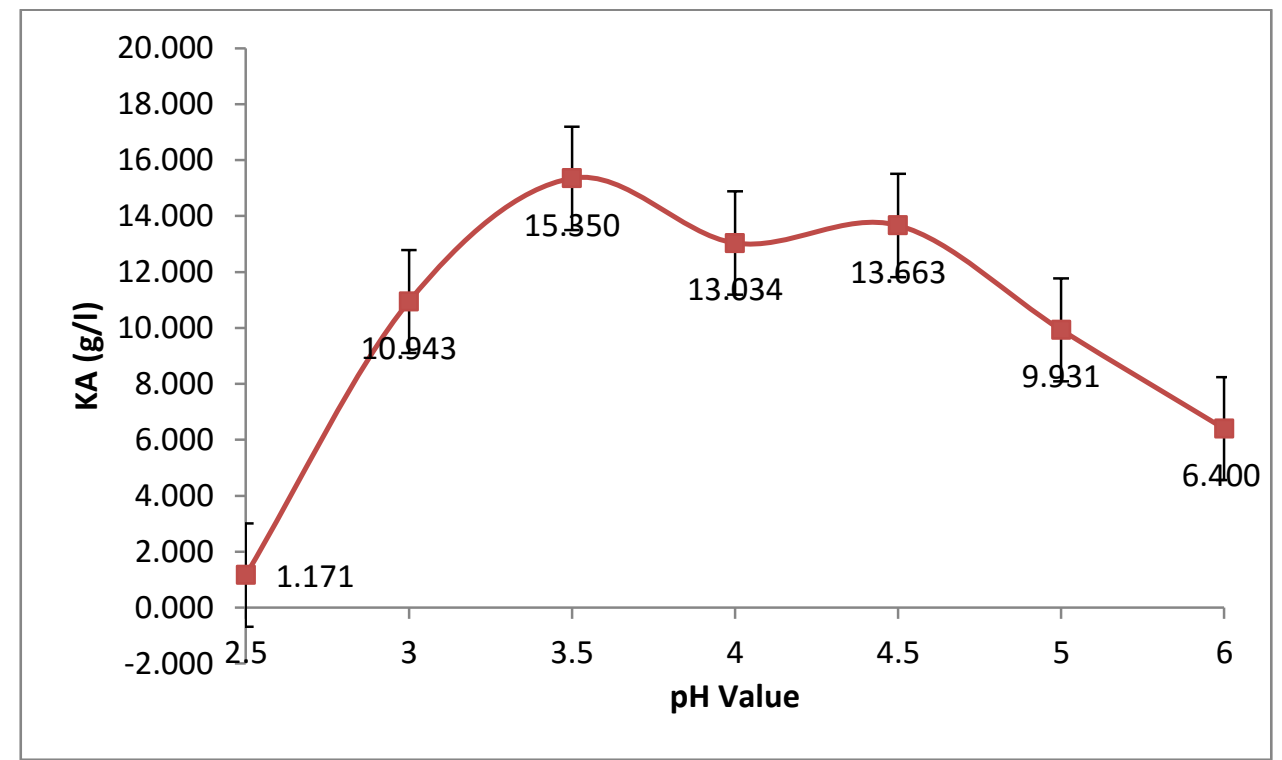

Fig. 4: Effect of Different Initial pH Values on Kojic Acid Production from Sugarcane Molasses by A. Oryzae 124A.

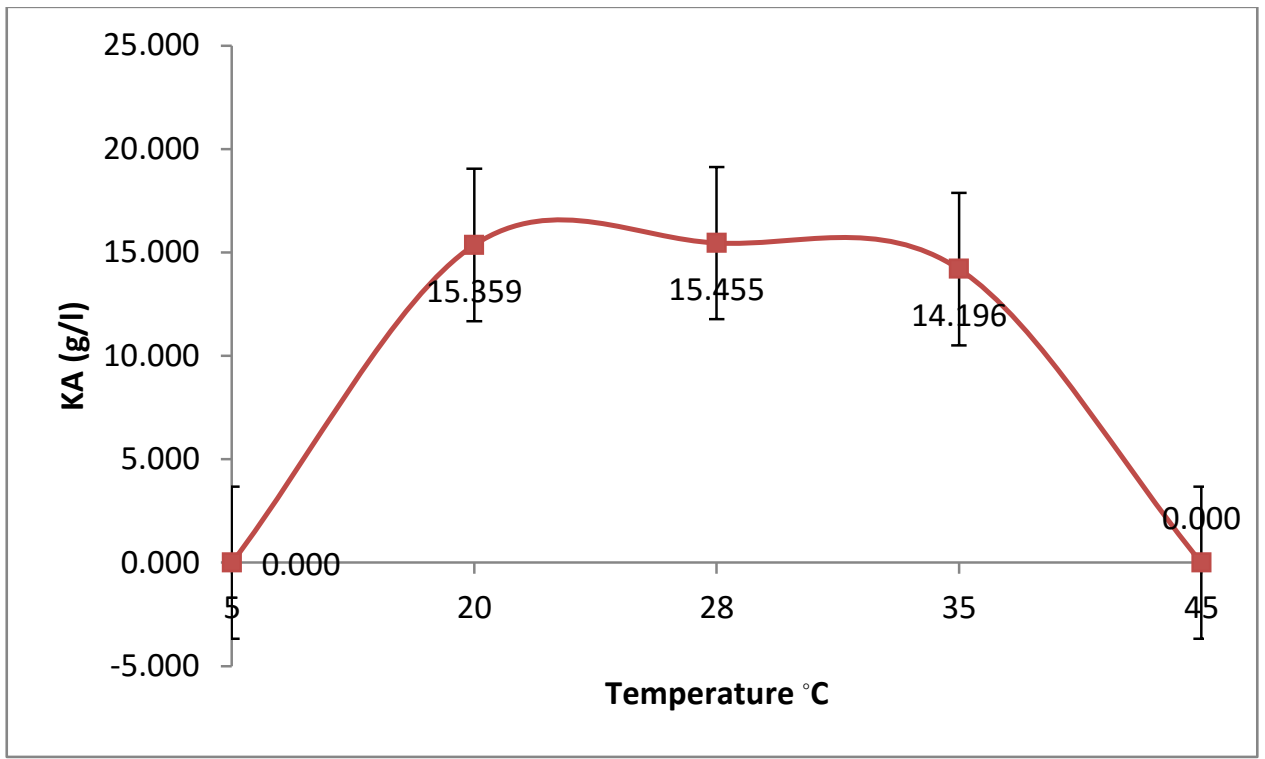

Fig. 5: Effect of Different Incubation Temperatures on Kojic Acid Production from Sugarcane Molasses by A. Oryzae 124A. 


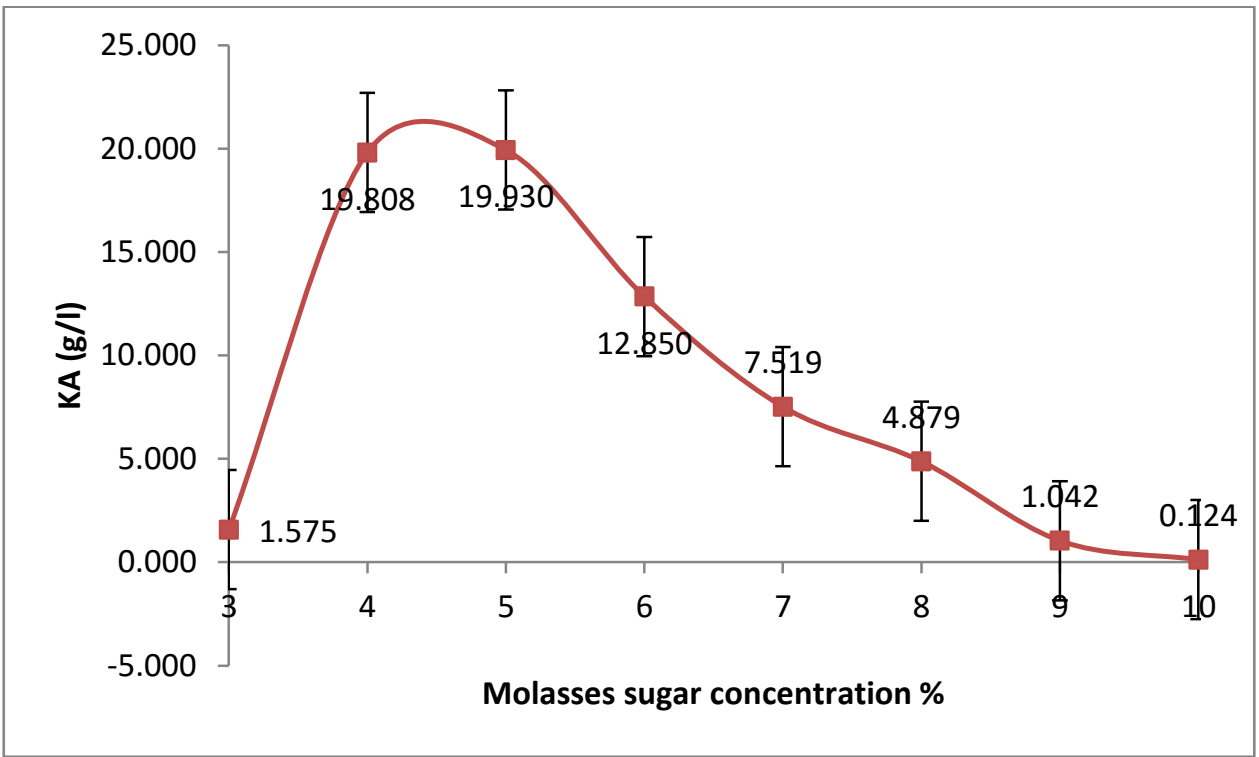

Fig. 6: Effect of Different Molasses Sugar Concentrations on Kojic Acid Production from Sugarcane Molasses by A. Oryzae 124A.

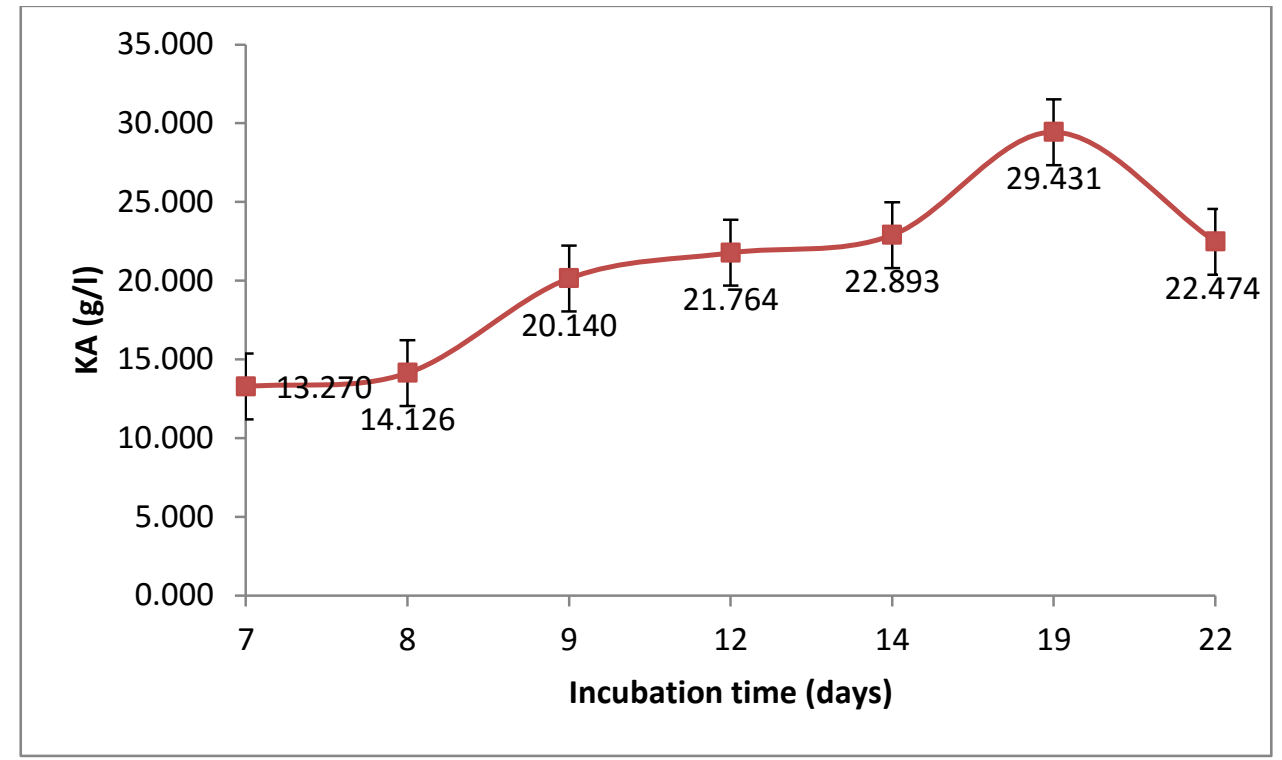

Fig. 7: Effect of Different Incubation Times on Kojic Acid Production from Sugarcane Molasses by A. Oryzae 124A.

This study explained that optimal fermentation conditions for kojic acid production by $A$. oryzae $124 \mathrm{~A}$ were $5 \%$ sugarcane molasses supplemented by $5.0 \mathrm{~g} / \mathrm{L}$ yeast extract, $1.5 \mathrm{~g} / \mathrm{L} \mathrm{KH}_{2} \mathrm{PO}_{4}$ and $0.5 \mathrm{~g} / 1 \mathrm{MgSO}_{4}$ substrate and nutrients. The optimal $\mathrm{pH}$, temperature, and incubation period as environmental conditions were $\mathrm{pH}$ $3.5,28{ }^{\circ} \mathrm{C}$, and 19 days, respectively. These results are completely similar to those recorded by several investigators (Arrif et al. 1997, Rosfarizan \& Ariff 2000, El-Kady et al. 2014).

\section{Conclusion}

Aspergillus oryzae 124A is very active and promising fungal strain for production of kojic acid from agro-industrial wastes such as sugarcane molasses and this will help in recycling the wastes by production of commercial products.

\section{Acknowledgements}

This research was supported by Suez University Fund.

\section{References}

[1] Al-Kahtani DF (2014) Isolation of Fungi and their Mycotoxin Extract from Stored Wheat and Other Grains Importer in Saudi Ara-

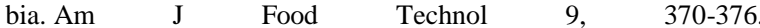
http://dx.doi.org/10.3923/ajft.2014.370.376.

[2] Ariff AB, Rosfarizan M, Herng LS, Madihah S \& Karim MIA (1997) Kinetics and modelling of kojic acid production by Aspergillus flavus link in batch fermentation and resuspended mycelial system. World J Microbiol Biotechnol 13 (2): 195201.http://dx.doi.org/10.1023/A:1018593815266.

[3] Ariff AB, Salleh MS, Ghani B, Hassan MA, Rusul G \& Karim, MIA (1996) Aeration and yeast extract requirements for kojic acid production by Aspergillus flavus Link. Enzyme Microbiol Techno 19: 545-550.http://dx.doi.org/10.1016/S0141-0229(96)00065-8.

[4] Ashari SE, Mohamad S, Ariff A, Basri M \& Salleh AB (2009) Optimization of enzymatic synthesis of palm-based kojic acid ester using response surface methodology. J Oleo Sci 58: 503510.http://dx.doi.org/10.5650/jos.58.503.

[5] Bajpai P, Agrawal PK \& Vishwanathan L (1982) Production of kojic acid by resuspended mycelial of Aspergillus flavus. Can J Microbiol 28: 1340-1346.http://dx.doi.org/10.1139/m82-200.

[6] Bentley R (2006) from miso, sake and shoyu to cosmetics: a century of science for kojic acid. Nat Prod Rep 23, 10461062.http://dx.doi.org/10.1039/b603758p.

[7] Brtko J, Rondahl L, Fickova M, Hudecova D, Eybl V \& Uher M (2004) Kojic acid and its derivatives: history and present state of art. Cent Eur J Public Health12: 16-18. 
[8] Buchta K (1982) Organic acids of minor importance. In Rehm HJ Reed GH \& Dellweg H (eds.) Biotechnology: A Comprehensive Treaties .3: Biomass, Microorganisms for Special Applications, Microbial Products, Energy from Renewable Resources. Ingelheim: Federal Republic of Germany.

[9] Burdock GA, Soni MG \& Carabin GI (2001) Evaluation of health aspects of kojic acid in food. Reg Toxicol Pharmacol 33: 80101.http://dx.doi.org/10.1006/rtph.2000.1442.

[10] Chakrabarti HS, Das S \& Gupta-Bhattacharya S (2012) Outdoor airborne fungal spora load in a suburb of Kolkata, India: its variation, meteorological determinants and health impact. Int J Environ Health Res 22: 37-50. http://dx.doi.org/10.1080/09603123.2011.588323.

[11] Chen JS, Wei CI, Rolle RS, Balaban MO, Otwell SW \& Marshall MR (1991) Inhibitory effect of kojie acid on some plant and crustacean polyphenol oxidases. J Agric Food Chem 39: 13961401.http://dx.doi.org/10.1021/jf00008a008.

[12] Christensen CM (1963) Influence of small differences in moisture content upon the invasion of harded winter wheat by Aspergillus restrictus and $A$. repens. Cereal Chem 40, 385-390.

[13] Clevstrom G \& Ljunggren H (1985) Aflatoxin formation and the dual phenomenon in Aspergillus flavus Link. Mycopathol 92: 129 139.http://dx.doi.org/10.1007/BF00437624

[14] Dowd PF (1988) Toxicological and biochemical interactions of the fungal metabolites fusaric acid and kojic acid with xenobiotics in Heliothis zea (F.) and Spodoptera frugiperda (J.E. Smith). Pestic Biochem Physiol 32: 123-134.http://dx.doi.org/10.1016/00483575(88)90005-3.

[15] Durugbo EU, Kajero AO, Omoregie EI \& Oyejide NE (2013) A survey of outdoor and indoor airborne fungal spora in the Redemption City, Ogun State, South-western Nigeria. Aerobiologia 29: 201-216. http://dx.doi.org/10.1007/s10453-012-9274-y.

[16] El-Aasar SA (2006) Cultural conditions studies on kojic acid production by Aspergillus parasiticus. Int J Agric Biol 8: 468-473.

[17] El-Kady IA, Zohri AA \& Hamed SR (2014) Kojic Acid Production from Agro-Industrial By-Products Using Fungi. Biotechnology Research International 2014: 110.http://dx.doi.org/10.1155/2014/642385

[18] El-Shanshoury AR, El-Sabbagh SM, Emara HA \& Saba HE (2014) Occurrence of moulds, toxicogenic capability of Aspergillus flavus and levels of aflatoxins in maize, wheat, rice and peanut from markets in central delta provinces, Egypt. Int J Curr Microbiol App Sci3 (3): 852-865.

[19] Emami S, Hosseinimehr SJ, Taghdisi SM \& Akhlaghpoor S (2007) Kojic acid and its manganese and zinc complexes as potential radioprotective agents. Bioorg Med Chem Lett 17: 4548.http://dx.doi.org/10.1016/j.bmcl.2006.09.097.

[20] Futamura T, Okabe M, Tamura T, Toda K, Matsunobu T \& Park Y. (2001) Improvement of production of kojic acid by a mutant strain Aspergillus oxyzae, MK 107-39. J Biosci Bioeng 91: 272 276.http://dx.doi.org/10.1016/S1389-1723(01)80133-X.

[21] Gad AS (2003) Modification of molasses for kojic acid production by Aspergillus parasiticus. N Egyptian J Microbiol 5: 14-26.

[22] Geiser DM, Pitt JI \& Taylor JW (1998) Cryptic speciation and recombination in the aflatoxin-producing fungus Aspergillus flavus. Proc Natl Acad Sci $95 \quad$ (1): 388 393.http://dx.doi.org/10.1073/pnas.95.1.388.

[23] Guibal E (2004) Interactions of metal ions with chitosan-based sorbents: A review. Sep Purif Technol 38: 43 74.http://dx.doi.org/10.1016/j.seppur.2003.10.004.

[24] Hassan HM, Saad AM, Hazzaa MM \& Ibrahim EI (2014) Optimization Study for the Production of Kojic Acid Crystals by Aspergillus oryzae var. effusus NRC 14 Isolate.Int J Curr Microbiol App Sci 3 (10): 133-142.

[25] Hazzaa MM, Saad AM, Hassan HM \& Ibrahim E (2013) High Production of Kojic acid crystals by isolated Aspergillus oryzae var. effuses NRC14. J Appl Sci Res 9 (3): 1714 - 1723.

[26] Hoekstra ES, Samson RA \& Summerbell RC (2004) Methodsfor the detection and isolation of fungi in the indoor environment. In:Samson RA, Hoekstra ES \& Frusavad JC (eds) Introduction to Food and Airborne fungi, 298-305.

[27] Horner WE, Worthan AG \& Morey PR (2004) Air- and dustborne mycoflora in houses free of water damage and fungal growth. Appl Environ

Microbiol 70 : 6400.http://dx.doi.org/10.1128/AEM.70.11.6394-6400.2004.

[28] Jignesh C, Pathak AN \& Sudarshan L (2014) Production Technology and Applications of Kojic Acid.Annu Res Rev Biol 4 (21): 3165-3196.http://dx.doi.org/10.9734/ARRB/2014/10643.
[29] Kacaniova M \& Tancinova D (2001) Natural occurrence of fungi in feeding wheat in the agricultural farm facilities. Acta Fytotech Zootech 4: 174-175.

[30] Kalyoncu F (2012) Relationship between airborne fungal allergens and meteorological factors in Manisa City, Turkey. Environ Monit Assess 165: 553-558. http://dx.doi.org/10.1007/s10661-009-0966$\underline{x}$.

[31] Khalifa MS (2003) Studies on production of single cell protein from vinasse. M.Sc. thesis, Sugar Technology Research Institute, Assiut University, Assiut, Egypt

[32] Khamaruddin NR, Basri M, Lian GEC, Salleh AB, Rahman RNZ Ariff AB, Mohamad R \& Awang R (2008) Enzymatic synthesis and characterization of palm-based kojic acid ester. J Oil Palm Res 20: 461- 469.

[33] Kitada M, Ueyama H \& Fukimbara T (1967) Studies on kojic acid fermentation (I) Cultural condition in submerged culture. J Ferment Technol 45: 1101-1107.

[34] Klich MA (2002) Identification of Common Aspergillus Species. Centraalbureau voor Schimmelcultures, Netherlands, ISBN-13 9789070351465, 116.

[35] Kotani T, Ichimoto I, Tatsumi C \& Fujita T. (1976) Bacteriostatic activities and metal chelation of kojic acid analogs. Agric Biol Chem, 40: $765-770$.

[36] Kwak MY \& Rhee JS (1992) Control mycelial growth for kojic acid production using ca-alginate immobilized fungal cells. Appl Microbiol Biotechnol 36: 583.http://dx.doi.org/10.1007/BF00183232.

[37] Lee YS, Park JH, Kim MH, Seo SH \& Kim HJ (2006) Synthesis of tyrosinase inhibitory kojic acid derivative. Archiv Pharm 339: 111 114.http://dx.doi.org/10.1002/ardp.200500213.

[38] Lekha PK \& Lonsane BK (1997) Production and application of tannin acyl hydrolase: State of the art. Adv Appl Microbiol 44: 215-260.http://dx.doi.org/10.1016/S0065-2164(08)70463-5.

[39] Lin C. (2001) the effect of equipping a non-waven fabrics in the fermenter on the production of kojic acid by Aspergillus flavus. M.Sc Thesis, Chemical Engineering, China.

[40] Lin MT, Mahajan JR, Dianese JC \& Takatsu A (1976) High production of kojic acid crystals by Aspergillus parasiticus UNBF A12 in liquid medium. Appl Environ Microbiol 32: 298-299.

[41] Masse MO, Duvallet V, Borremans M \& Goeyens L (2001) Identification and quantitative analysis of kojic acid and arbutine in skinwhitening cosmetics. Int J Cosmet Sci 23: 219. 232.http://dx.doi.org/10.1046/j.1467-2494.2001.00074.x.

[42] May OE, Moyer AJ, Wells PA \& Herbik H (1931) the production of kojic acid by Aspergillus flavus. J Am Chem Soc 53: 774 782.http://dx.doi.org/10.1021/ja01353a050.

[43] Megalla R \& Polasa H (1985) Inhibition of growth of kojic acid biosynthesis in Aspergillus by some chlorinated hydrocarbons. Indian J Microbiol 25: 21-25.

[44] Megalla SE, Bennett GA, Ellis JJ \& Shotell OI (1986) Production of deoxynivalenol and zearalenone by isolates of Fusarium graminearum SCHW. J Basic Microbiol $26 \quad$ (7): 415 419.http://dx.doi.org/10.1002/jobm.3620260709.

[45] Menezes EA (2004) airborne fungi isolated from Fortaleza city, State of Ceara, Brazil. Rev Inst Med Trop S Paulo 46:133-137. http://dx.doi.org/10.1590/S0036-46652004000300003.

[46] Mohamad R \& Ariff AB (2007) Biotransformation of various carbon sources to kojic acid by cell-bound enzyme system of $A$. flavus link 44-1. Biochem Eng J 35 (2): 203 209.http://dx.doi.org/10.1016/j.bej.2007.01.015.

[47] Moubasher AH (1993) Soil fungi in Qatar and Arab countries. The Scientific and Applied Research Centre, University of Qatar, Doha, Qatar: 566.

[48] Noh JM, Kwak SY, Seo HS, Seo JH, Kim BG \& Lee YS (2009) Kojic acidamino acid conjugates as tyrosinase inhibitors. Bioorg Med Chem $\quad$ Lett 19 : 5586 5589.http://dx.doi.org/10.1016/j.bmcl.2009.08.041.

[49] Nohynek GJ, Kirkland D, Marzin D, Toutain H, Leclerc-Ribaud C \& Jinnai H (2004) An assessment of the genotoxicity and human health risk of topical use of kojic acid [5-hydroxy-2(hydroxymethyl)-4H-pyran-4-one]. Food Chem Toxicol 42: 93105.http://dx.doi.org/10.1016/j.fct.2003.08.008.

[50] Ogawa A, Wakisaka Y, Tanaka T, Sakiyama T \& Nakanishi K (1995) Production of kojic acid by membrane-surface liquid culture of Aspergillus oryzae NRRL484. J Ferment Bioeng 80: 4145.http://dx.doi.org/10.1016/0922-338X(95)98174-J.

[51] Rasmey AM (2009) Biotransformations of steroids by some local fungi belonging to order Mucorales isolated from the New Valley area, Egypt. M. Sc. Thesis, Faculty of Science, Assiut University, Egypt. 
[52] Reddy KRN, Reddy CS \& Muralidharan K (2009) Detection of Aspergillus spp. and aflatoxin B1 in rice in India. Food Microbiol 26: 27-31.http://dx.doi.org/10.1016/j.fm.2008.07.013.

[53] Rosfarizan M, Mohd SM, Nurashikin S, Madihah MS \& Arrif AB (2010) Kojic acid: Applications and development of fermentation process for production. Biotechnol Mol Biol Rev 5 (2): 24-37.

[54] Rosfarizan M \& Ariff AB (2000) Kinetics of kojic acid fermentation by Aspergillus flavus using different types and concentrations of carbon and nitrogen sources. J Indus Microbiol Biotech 25 (1): 20-24.http://dx.doi.org/10.1038/sj.jim.7000017.

[55] Rosfarizan M, Ariff AB, Hassan MA \& Karim MI (2000) Influence of $\mathrm{pH}$ on kojic acid fermentation by Aspergillus flavus. Pakistan J Biol Sci 3: 977-82.http://dx.doi.org/10.3923/pjbs.2000.977.982.

[56] Rosfarizan M, Madihad S \& Ariff AB (1998) Isolation of kojic acid producing fungus capable of using starch as a carbon source. Lett Appl Microbiol26: 27-30.http://dx.doi.org/10.1046/j.1472765X.1998.00263.x.

[57] Roukas T (1993) Ethanol production from carob pods by Saccharomyces cerevisiae. Food Biotechnol 33: 805-810.

[58] Rustemeyer SM, Lamberson WR, Ledoux DR, Rottinghaus GE, Shaw DP, Cockrum RR, Kessler KL, Austin KJ \& Cammack KM (2010) Effects of dietary aflatoxin on the health and performance of growing barrows. J Anim Sci 88: 3624 3630.http://dx.doi.org/10.2527/jas.2009-2663.

[59] Sahasrabudhe NA \& Sankpal NV (2001) Production of organic acids and metabolites on fungi and applications in food industry, In: Khachatourians GG \& Arora DK (eds.), App. Myc. and biotech., agriculture and food production, 1, Elsevier; Amsterdam, pp. 387425.http://dx.doi.org/10.1016/S1874-5334(01)80016-2.

[60] Saruno R, Kato F \& Ikeno T (1978) Kojic acid, a tyrosinase inhibitor from Aspergillus albus. Agric Biol Chem 43: 1337-1338.

[61] Sen B \& Asan A (2009) fungal flora in indoor and outdoor air of different residential houses in Tekirdag City (Turkey): seasonal distribution and relationship with climatic factors. Environ Monit Assess 151: 209-219. http://dx.doi.org/10.1007/s10661-008-0262-1.

[62] Shams-Ghahfarokhi M, Aghaei-Gharehbolagh S, Aslani N \& Raz zaghi-Abyaneh M (2014) Investigation on distribution of airborne fungi in outdoor environment in Tehran, Iran. J Environ Health Sci Eng 12: 54.http://dx.doi.org/10.1186/2052-336X-12-54

[63] Shashank I (1994) Effect of pretreatment of molasses and post treatment of fermented broth in industrial production of ethanol. App Microbiol Biotechnol 45 (1): 181-187.

[64] Soliman HM (2003) Mycoflora and Mycotoxins of Cereal Grains in Delta, Egypt. Mycobiolo31 (4): 190.http://dx.doi.org/10.4489/MYCO.2003.31.4.183.

[65] Synytsya A, Blafkova P, Synytsya A, Copikova J, Spevacek J \& Uher M (2008) Conjugation of kojic acid with chitosan. Carbohydr Polym 72: 21-31.http://dx.doi.org/10.1016/j.carbpol.2007.07.011.

[66] Tanigaki H, Obata H \& Tokuyama T (1980) the determination of kojic acid using the stopped-flow method. Bulletin of the Chemical Society of Japan 35: 31953197.http://dx.doi.org/10.1246/bcsj.53.3195.

[67] Vonberg RP \& Gastmeier P (2006) Nosocomial aspergillosis in outbreak settings. J Hosp Infect 63: 246254.http://dx.doi.org/10.1016/j.jhin.2006.02.014.

[68] Wood BJB (1998) Microbiology of Fermented Food (2nd Edition), Springer, London.

[69] Yasunobu T, Motoaki S, Noriko Y, Junichiro M, Koichi M., Junichi $S$ et al. (2010) Identification and characterization of genes responsible for biosynthesis of kojic acid, an industrially important compound from Aspergillus oryzae. Elsevier Inc 47:953-961. 